\title{
Meteoro da ilusão: sentidos do trabalho para jovens gerentes de bancos públicos
}

\author{
ELENA BANDEIRA DA SILVA ${ }^{1}$ \\ ISABEL DE SÁ AFFONSO DA COSTA ${ }^{1}$ \\ JoRge AUgusto de SÁ BRITO E Freitas ${ }^{1}$ \\ DeNISE MedeIROS Ribeiro SALLES ${ }^{2}$
}

${ }^{1}$ UniVersidade EstácIO de SÁ (UNESA) / MESTRAdo EM AdMINISTRAÇÃo E DESENVOLVIMENTO EMPRESARIAL, RIO DE JANEIRO - RJ, BRASIL

${ }^{2}$ Universidade Federal Fluminense (UFF) / Programa de Pós-Graduação em AdMinistração, Niteró - RJ, BRASIL

\begin{abstract}
Resumo
Este artigo apresenta resultados de pesquisa relativa ao sentido do trabalho para os jovens gerentes de bancos públicos, norteada pela Teoria das Representações Sociais. A abordagem é qualitativa, do tipo descritivo-interpretativa. Aplicaram-se técnicas de entrevista semiestruturada, complementação de sentenças e elaboração de desenhos em 17 participantes em Porto Alegre/RS, Rio de Janeiro/RJ e Vitória/ES; explicitaram-se os processos de objetivação e ancoragem na elaboração das 37 representações sociais do trabalho identificadas, agrupadas em torno dos núcleos centrais "organização provedora e protetora", "organização cobradora, ameaçadora e com foco nos lucros" e "organização pública". Tais representações evidenciaram intensa associação entre trabalho e dinheiro, além do caráter ilusório e ambíguo do cargo, fonte de prazer e sofrimento. Os resultados sugerem aplicabilidade na revisão das práticas de gestão de pessoas, tais como envolvimento dos gerentes com a saúde física e mental dos trabalhadores, transparência dos processos, clareza sobre os papéis e as expectativas do trabalho nos bancos. O mais relevante é gerar insumos para a busca de mecanismos que favoreçam o respeito aos limites físicos, mentais e psicoafetivos dos profissionais, em busca de resultados sustentáveis para trabalhadores e organizações.
\end{abstract}

Palavras-chave: Sentido do trabalho. Representações sociais. Gerentes. Bancos públicos.

\section{Meteor of illusions: The meaning of work for young public bank managers}

\begin{abstract}
This article presents the results of research on the meaning of work for young managers of Brazilian public banks, guided by the social representation theory. This was a qualitative, descriptive-interpretative study. Semi-structured interviews and projective techniques of drawing and sentence completion were applied to 17 participants in the cities of Porto Alegre, Rio de Janeiro and Vitória. The process of objectification and anchoring carried out in the elaboration of the 37 social representations about the work grouped around the three dimensions: "provider and protective organization," "demanding, threatening, and profit-oriented organization," and "public organization." The representations evidenced a strong association between work and money, along with the illusory and ambiguous character of the managerial position, source of pleasure and suffering. Results suggest applicability in reviewing people management practices such as managers' involvement with workers' physical and mental health, transparency, and clarity about the roles and expectations of work within banks. The findings suggest the need for tools that respect the professionals physical, mental, and psycho-affective limits, leading to sustainable results both for workers and organizations.
\end{abstract}

Keywords: Meaning of work. Social representations. Managers. Public banks.

\section{Meteoro de ilusiones: significado del trabajo para jóvenes gerentes de bancos públicos}

\section{Resumen}

Este artículo presenta resultados investigativos acerca del sentido del trabajo para los jóvenes gerentes de bancos públicos, orientados por la Teoría de las Representaciones Sociales. El análisis es cualitativo, del tipo descriptivo-interpretativo. Se han aplicado técnicas de entrevista semiestructurada, complementación de frases y elaboración de diseños a 17 participantes de Porto Alegre, Rio de Janeiro y Vitória, Brasil; se han explicitado los procesos de objetivación y anclaje en la elaboración de 37 representaciones sociales de trabajo identificadas, agrupadas alrededor de los núcleos "organización proveedora y protectora", "organización controladora, amenazadora y concentrada en los lucros" y "organización pública”. Tales representaciones han evidenciado una intensa asociación trabajo-dinero, además del carácter ilusorio y ambiguo del puesto, fuente de placer y sufrimiento. Los resultados sugieren su aplicabilidad en la revisión de las prácticas de gestión de personas, tales como compromiso de los gerentes con la salud física y mental de los trabajadores, trasparencia de los procesos, claridad respecto a los roles y expectativas del trabajo en los bancos. Lo más relevante es el generar insumos para la búsqueda de mecanismos que favorezcan el respeto a los límites físicos, mentales y psicoafectivos de los profesionales, hacia resultados sostenibles para trabajadores y organizaciones.

Palabras clave: Sentido del trabajo. Representaciones sociales. Gerentes. Bancos públicos. 


\section{INTRODUÇÃO}

Meteoros são fenômenos que ocorrem em alta velocidade na atmosfera terrestre, decorrentes dos movimentos do planeta. Por analogia, pensando-se em termos de altura e velocidade, pode-se considerar meteórica uma carreira que oferece a oportunidade de ascensão rápida ao profissional. Porém, se esse crescimento ocorrer à custa do bem-estar do sujeito, esse sucesso o aprisiona e pode resultar em adoecimento, revelando-se ilusório.

As organizações correspondem ao espaço onde o homem manifesta, além da racionalidade necessária à realização de negócios, seus sonhos, medos e paixões (ENRIQUEZ, 1997). Portanto, as organizações emergem da interação entre pessoas reunidas em busca de objetivos pessoais e empresariais.

Agências bancárias são alguns desses lugares de encontro entre o individual e o coletivo. Nas agências bancárias desenvolvem-se e mesclam-se crenças, valores, significados, afetos e contradições dos profissionais que dedicam seus corpos, pensamentos, emoções e energias às atividades laborais. Ambientes intensivos em cobrança por resultados objetivos, ali o desempenho de cada empregado pode ser controlado por meio de eficientes sistemas eletrônicos funcionando em tempo real, ao modo da vigilância panóptica foucaultiana. Gaulejac (2014) aponta que o mercado financeiro é o epicentro do capitalismo na atualidade; nele, como em nenhum outro lugar, evidenciam-se os conflitos inerentes às relações de poder estabelecidas pela divisão social do trabalho.

Do ponto de vista psicanalítico, as organizações ocuparam o lugar de outras instituições, como a família, a igreja e os relacionamentos na vida dos indivíduos (FREITAS, 2002). A organização alcança o inconsciente do sujeito, levando-o a amar as próprias dificuldades e chamá-las de desafios. Há um distanciamento do sujeito de si mesmo, que se mantém obnubilado quanto aos próprios desejos, necessidades e sonhos, confundidos com os objetivos organizacionais. Diariamente a pessoa é condicionada a gostar de pertencer àquele grupo, àquele mecanismo, naturalizando o viver diariamente sob tensão.

O trabalho é um espaço de construção de sentidos, identidade e historicização do sujeito (DEJOURS, ABDOUCHELI e JAYET, 2009). Estudos mostram que, para os brasileiros, o trabalho continua central e constitutivo do sujeito (MOTA, 2012). Cabe, então, ao campo da Administração intensificar as pesquisas sobre o sentido do trabalho, delimitando-o para possibilitar a aproximação da realidade em questão e, assim, melhor compreendê-la.

Este artigo apresenta resultados de pesquisa que teve como objetivo explicar como são criados os sentidos do trabalho pelos jovens gerentes de bancos públicos, tendo como base suas representações da vivência do trabalho - em tempos de rápidas transformações, desenvolvimento tecnológico, trocas interculturais globais e instantaneidade.

O ingresso nos bancos públicos ocorre por meio de concurso, motivo pelo qual a demissão de empregados deve ser justificada e precedida de processo administrativo. Já a função de confiança é discricionária, restringe-se aos bancos empregadores, de modo que tanto a designação quanto a dispensa, a qual resulta em decesso, ficam a critério do gestor. Essa diferença em relação ao setor privado levou à delimitação do grupo participante em gerentes de bancos públicos, pois se entendeu que a segurança no emprego pode afetar a percepção do trabalho.

Para o objetivo proposto, usou-se como referencial teórico e analítico a Teoria das Representações Sociais (TRS) (MOSCOVICI, 2004, 2015). A TRS concentra-se no conhecimento produzido pelo senso comum, nas práticas do cotidiano, construído e reconstruído nas inter-relações entre indivíduos e grupos. Por meio da linguagem e da comunicação são produzidos significados em determinados contextos e condições histórico-culturais específicas, numa estrutura holística e dinâmica (MARKOVÁ, 2017).

Entende-se que a proposta da TRS alinha-se às teorias organizacionais, especialmente as de viés interpretativo e crítico, oferecendo novas perspectivas à descrição do fenômeno estudado (MARTINS-SILVA, SILVA JUNIOR, PERONI et al., 2016). Pesquisadores críticos como Gaulejac (2014), Enriquez (2014) e Morgan (2011) defendem a reflexividade dos indivíduos como atores ativos na construção do sentido de suas vivências no trabalho, assim como faz Moscovici, o propositor da TRS (MOSCOVICl, 2015).

Este artigo é estruturado em quatro partes, além desta introdução. Na primeira parte são sistematizadas contribuições teóricas relativas ao tema; na segunda apresentam-se informações sobre a metodologia de pesquisa; na terceira integram-se as informações coletadas por meio da triangulação metodológica, com análises alinhadas à TRS; na quarta e última parte apresentam-se as conclusões deste estudo. 


\section{REFERENCIAL TEÓRICO}

De acordo com a TRS, apresentada por Moscovici em sua tese de doutoramento, La psychanalyse, son image et son public (MOSCOVICI [1961], 2004), indivíduos e grupos produzem e compartilham conhecimento nas suas inter-relações e experiências cotidianas; essas interações resultam em senso comum que interfere em pensamentos e comportamentos e é representado por imagens, permitindo a interação entre a realidade e o mundo das ideias (MOSCOVICI, 2004, 2015). Para Jodelet (2001, p. 17), as representações sociais são “[...] realidades mentais cuja evidência nos é sensível cotidianamente [...], são trazidas pelas palavras [...], cristalizadas em condutas e em organizações materiais e espaciais".

As representações sociais são elaboradas por meio de dois processos simultâneos, a ancoragem e a objetivação. A ancoragem permite a interpretação e a gestão do ambiente, o sujeito compara algo estranho com um paradigma de uma categoria que considera apropriada, familiarizando-se. Já a objetivação torna o abstrato concreto, reproduz um conceito em uma imagem. Trata-se de um processo contínuo no qual o sujeito incorpora ou assimila novos elementos ao compará-los ao que já existe na própria memória (ALMEIDA, SANTOS e TRINDADE, 2014; MOSCOVICI, 2015).

As representações reúnem os conhecimentos acumulados pela experiência pessoal, como também os científicos, ideológicos e culturais, os quais, compartilhados, resultam em senso comum que orienta as ações dos integrantes do grupo (JODELET, 2001). Aspectos históricos, culturais e societais articulam-se na produção das representações sociais, misturando crenças, valores e afetos do sujeito. Assim, os sujeitos devem ser concebidos no contexto social concreto, representado pelas esferas de pertença das representações, como mostrado na Figura 1.

Figura 1

\section{As esferas de pertença das representações sociais}

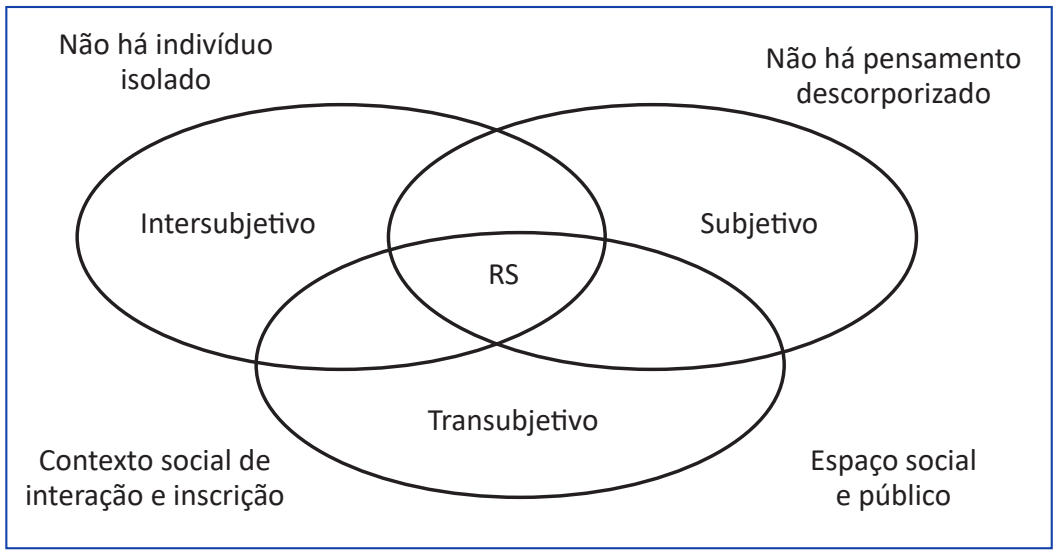

Fonte: Adaptado de Jodelet (2009, p. 697).

A esfera da subjetividade refere-se à sensibilidade, às emoções, às experiências e aos saberes adquiridos. A esfera da intersubjetividade refere-se a trocas, consenso ou dissensão, representações compartilhadas. Já a transubjetividade abarca as ideias, os conhecimentos, os valores e as condutas que indivíduos e grupos têm em comum, incluindo relações de poder e aspectos ideológicos. As representações sociais pertencem à interseção entre esses processos, cuja abordagem deve ser conjunta e interdisciplinar (JODELET, 2009).

As representações sociais organizam-se em torno de um "[...] núcleo central, elemento fundamental da representação, pois é ele que determina ao mesmo tempo sua significação e sua organização" (ABRIC, 2001, p. 163). Esse núcleo é de natureza cognitivo-afetiva e é o seu elemento mais estável, já "[...] a periferia é heterogênea, é onde as circunstâncias transformam as representações" (ARRUDA, 2014, p. 449). Mudanças na representação social exigem alterações no núcleo central, que funciona como princípio organizador e tem caráter estrutural. Os esquemas periféricos do núcleo central absorvem pequenos desacordos com a realidade, preservando-o. A permanência da contradição entre a realidade e a representação é que pode transformá-la, fazendo-a mudar de significação (FLAMENT, 2001). 
Originada no bojo da psicanálise, a TRS permite trazer ao nível consciente conteúdos muitas vezes inconscientes, por meio da interpretação de atos falhos, de palavras, discursos e condutas, alcançando a complexidade dos eventos organizacionais. Pesquisando as representações sociais de trabalhadores da indústria petrolífera cujo trabalho é realizado em espaço isolado, Salles e Costa (2013) descobriram que eles sentiam falta dos capacetes quando não estavam em serviço, pois ficavam sem referências. Isso mostra que, nas rotinas e hábitos adquiridos no cotidiano, as representações do trabalho podem passar despercebidas.

Nos estudos organizacionais encontram-se autores que, também inspirados na psicanálise, reconhecem a necessidade de mudanças estruturais nas relações produtivas, têm convicção da reflexividade do sujeito e lançam olhar crítico sobre as relações vividas no mundo organizacional. Explicitam o jogo de poder e força, a busca por resultados cada vez mais passíveis de medição e associados ao lucro - o que pode reforçar personalidades perversas, insensíveis e impermeáveis a sentimentos (GAULEJAC, 2014). Não alcançar o sucesso gera sentimentos de culpa e vergonha perante o desempenho insatisfatório frente a metas cada vez mais inalcançáveis (ENRIQUEZ, 2014). Assim, condenado a vencer, o sujeito obriga-se a trabalhar cada vez mais e melhor, alienando-se da própria realidade interior, renunciando a si mesmo e perdendo sua liberdade para satisfazer a uma ambição sem fim (MORGAN, 2011; PAGÈS, BONETTI, GAULEJAC et al., 2006).

No trabalho, o sujeito confronta-se com angústias existenciais preexistentes, e com as restrições impostas pela organização na qual está inserido (DEJOURS, 1999, 2009). Ao mesmo tempo, o trabalho é fonte de prazer, na medida em que permite ao indivíduo atualizar sua capacidade criativa e sublimatória. Assim, a construção do sentido do trabalho é uma experiência psicossocial de prazer e sofrimento, que pode trazer equilíbrio psíquico ou adoecimento. Para Enriquez (2002), o sentido positivo de prazer no trabalho está relacionado à possibilidade de fazer uma obra, de existir, de ter uma identidade: um trabalho com sentido é aquele no qual o sujeito transforma algo e, assim, transforma a si mesmo (SILVA e COSTA, 2015).

Há, então, necessidade de desenvolver estratégias de sobrevivência diante das mutações do trabalho, o que resulta em condutas muitas vezes alienantes, ou mesmo avassaladas ao sistema, em troca de conforto e segurança (THIRY-CHERQUES, 2004). Para Gaulejac (2014, p. 127), o paradoxo entre as vantagens e desvantagens da vida organizacional - que confere autonomia ao sujeito ao mesmo tempo que o torna dependente - produz "alienação à segunda potência", aumentando o risco de que o sujeito funcione de modo robotizado, deixe de produzir sentido para o trabalho, viva uma crise de valores, uma busca ilusória e contínua, não se sabe do quê.

No ambiente bancário, a adoção de novas tecnologias produtivas tem causado a redução de postos de trabalho, gerando intensa pressão, cotidianamente vivenciada pelos profissionais do meio (RESENDE e MENDES, 2004).

A história dos bancários nos bancos públicos é marcada pela reforma administrativa do Estado implementada pelo governo brasileiro a partir da década de 1990. Voltada à obtenção de resultados, com base na eficiência da máquina administrativa, tinha entre seus objetivos reduzir a participação do Estado nas atividades econômicas (BRESSER-PEREIRA, 1998). Grandes instituições estrangeiras investiram no mercado nacional por meio de fusões e aquisições. Segundo Freitas (2005), em 2002, entre os 50 maiores bancos brasileiros, 17 já eram controlados por estrangeiros. Dinkings (2002) relata que em março de 2000 havia nove bancos públicos de atendimento varejista. Hoje são cinco, segundo dados do Banco Central (2017), e apenas um é $100 \%$ público, os demais são de economia mista.

O setor financeiro é o que mais investe em tecnologia, e noticia o forte crescimento dos canais remotos suportados por internet ou telefonia, como o mobile banking, cujo número total de transações dobrou a cada ano no período entre 2014 e 2016. Isoladamente, as transações on-line com movimentação financeira cresceram 140\% (FEBRABAN, 2017, p. 50), evidenciando que a execução dos serviços está sendo transferida dos bancários para os clientes. A quantidade de postos de trabalho em

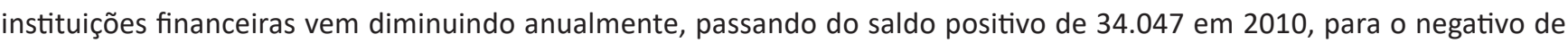
(-)11.486 em novembro de 2017 (MTE/CAGED/ 2018).

Os investimentos em automação dos serviços repetitivos facilitaram a formação de uma categoria chamada bancáriovendedor, responsável pela venda dos novos produtos ofertados pelos bancos, tais como cartões de crédito, seguros e títulos de capitalização (JINKINGS, 2002). Esses profissionais têm renda variável, cuja progressão é vinculada ao desempenho individual, acompanhado diariamente. Além de levar o sujeito a pensar que a progressão funcional depende exclusivamente dele, tal modo de gestão gera um clima de competição que resulta em relações interpessoais fragilizadas, em um ambiente profissional de tensões, fonte de angústia, medo e sofrimento, cuja causa reside principalmente nas inalcançáveis metas de produtividade (BRUNO, 2011). 
Pesquisa com foco nas trajetórias profissionais de gerentes de bancos públicos e privados concluiu que "[...] a lógica do sistema financeiro é a da pressão: pressão por resultados, por aperfeiçoamentos teóricos, por constante atualização, pela manutenção do emprego e status social e por dedicação à empresa" (MÁXIMO, ARAÚJO, ZAMBRONI-DE-SOUZA et al., 2011, p. 70). O setor financeiro inclui-se entre os ambientes organizacionais descritos por Seligmann-Silva (2004) como espaços em que o mal-estar no trabalho é escondido e mascarado. Ali, à exceção do entusiasmo, emoções e sentimentos são vistos de forma negativa, em vista do que há apelo ao uso de remédios, álcool e drogas para resistir à pressão psíquica e parecer bem.

Em razão da intensa competitividade e pressão que acomete o setor bancário, a investigação e as revelações sobre o sentido do trabalho para jovens gerentes de bancos públicos poderão contribuir para o aprofundamento de reflexões e ações inerentes à relação trabalhador-trabalho.

\section{METODOLOGIA}

A presente pesquisa teve abordagem qualitativa, abarcando opiniões e perspectivas no contexto específico em que os indivíduos acumulam experiências (YIN, 2016). O método interpretativo-descritivo foi aplicado para interpretação de testes projetivos e análise do discurso, à luz da TRS. Para a análise indutiva, como recomendado por Creswell (2010), foram escolhidos, por acessibilidade, 17 jovens gerentes, com idade máxima de 35 anos e tempo mínimo de dois anos no exercício da função, todos lotados em agências de atendimento de quatro bancos públicos.

A pesquisa de campo foi realizada com 3 participantes em Porto Alegre/RS, 10 no Rio de Janeiro/RJ e 4 em Vitória/ES, a partir de setembro de 2017. Foram visitadas 29 agências bancárias em busca de profissionais que atendessem aos critérios da pesquisa. Nessas ocasiões a pesquisa e seus objetivos eram apresentados, enfatizando-se aspectos relativos à confidencialidade e ao anonimato da participação. Houve também oportunidade de realizar observação não estruturada dos ambientes, favorecendo a interpretação dos dados.

Para a investigação foram aplicadas: i) técnicas projetivas de elaboração de desenho (mediante o estímulo "o que o trabalho como gerente de banco público representa para mim") e complementação de sentenças (30 sentenças livremente complementadas por participante, tais como "o trabalho significa...", "o mais importante no meu trabalho é ...", "no meu trabalho gosto quando..." e "no meu trabalho sofro quando..."); ii) entrevista semiestruturada.

A técnica de desenho foi utilizada no início das entrevistas e serviu como direcionador. Os desenhos foram analisados e interpretados com base em Augras (1998), Silva (1981), Van Kolck (1981) e Anzieu (1978). Assim, foram consideradas a responsividade, a atitude adaptativa e de aceitação da proposta. Foram observados a posição do papel, o tamanho do desenho, das letras, a posição na folha e até as cores escolhidas. Durante a projeção foram objetos de observação o comportamento, as expressões faciais, eventuais comentários ou quaisquer acontecimentos, e depois o grafismo - proporções, traçados, posição da figura, figura e fundo, moldura e outros. Durante a entrevista houve, ainda, oportunidade de falar sobre o desenho.

Inicialmente procedeu-se à interpretação individual das evidências obtidas por meio dessas técnicas (projetivas e entrevistas). Para cada participante foi elaborado um mapa de objetivação e ancoragem. A presença de itens repetidos por diferentes participantes evidenciou padrões estruturais reveladores das percepções e dos sentidos manifestados, fossem eles explícitos ou subjacentes aos discursos.

\section{ANÁLISE DOS RESULTADOS}

Em relação ao perfil dos participantes, destaca-se que há 12 casados, 4 solteiros e um divorciado. Seis têm filhos. Quanto à escolaridade, todos são graduados, predominando os cursos de Direito (6) e Administração (5). Pós-graduação foi cursada por 11 participantes. 0 tempo médio de banco é de 10 anos e o de exercício do cargo gerencial é de seis, mas outras funções de confiança de natureza técnica eram exercidas antes da assunção da gerência.

A seguir, no Quadro 1, são apresentados os desenhos, analisados individualmente, identificados por um código que informa a ordem numérica da entrevista, de 1 a 17; a cidade de origem, sendo V=Vitória, P=Porto Alegre e R=Rio de Janeiro; o gênero, sendo $\mathrm{F}=$ feminino e $M=$ masculino. Depois indica-se a idade, seguida do tempo de banco e, por último, tempo de gerência, 
ambos em anos. Assim, por exemplo, P1VM35,10-6 corresponde ao participante 1, da cidade de Vitória/ES, gênero masculino, 35 anos de idade, 10 anos de banco e seis de gerência.

\section{Quadro 1}

\section{Desenhos e suas interpretações}

\begin{tabular}{|c|c|}
\hline Fonte: P1VM35, 10-6. & $\begin{array}{l}\text { O leão representa a força e a agressividade } \\
\text { indispensáveis à atuação no ambiente do mercado } \\
\text { financeiro. A figura evidencia contradição entre } \\
\text { a autoimagem e o que é comunicado sobre si } \\
\text { no discurso verbal. Esquiva-se de abstrações e } \\
\text { busca o domínio da razão. Mostra-se orientado } \\
\text { ao concreto. Aborda preferencialmente questões } \\
\text { operacionais, evita explicitar subjetividades. O leão } \\
\text { representa, segundo Augras, (1998, p. 122), “[...] } \\
\text { a dominação dos instintos, a sublimação”, e pode } \\
\text { também revelar castração. }\end{array}$ \\
\hline Fonte: P2VM31, 10-6. & $\begin{array}{l}\text { O trabalho é para obtenção do sustento. Prazeroso } \\
\text { seria realizar um trabalho do qual realmente goste. } \\
\text { Bancário não é profissão, não foi uma escolha, um } \\
\text { desejo. Qualquer outra escolha de trabalho teria } \\
\text { que reunir satisfação pessoal e dinheiro, como um } \\
\text { cargo de advogado no setor jurídico da organização. } \\
\text { Projeta um temperamento adaptativo, desinibição } \\
\text { e expansividade, energia e objetivos altos, sem } \\
\text { perder o contato com a realidade. Sente-se à } \\
\text { vontade com o poder de decisão e autonomia } \\
\text { negocial, demonstra confiança em si e uma forte } \\
\text { estrutura do ego. }\end{array}$ \\
\hline 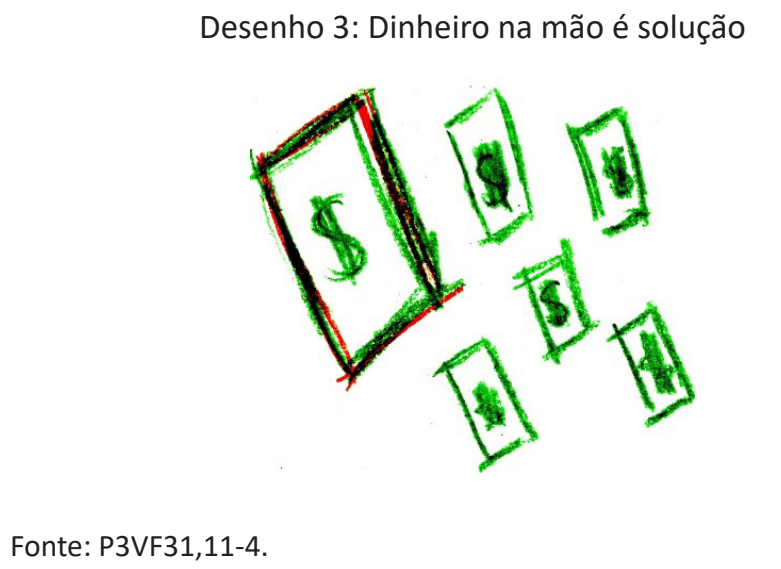 & $\begin{array}{l}\text { O trabalho é importante como meio de ganhar } \\
\text { dinheiro. Considera que tem desenvoltura ao } \\
\text { falar e capacidade de convencimento, focaliza os } \\
\text { resultados, graças ao predomínio da racionalidade. } \\
\text { Excelente vendedora, é capaz de duplicar a renda } \\
\text { mensal pelo ganho de comissões de vendas. } \\
\text { Assim, a função gerencial representa conquistas } \\
\text { financeiras, independência nessa área, ajuda à } \\
\text { família e consumo. }\end{array}$ \\
\hline Desenho 4: Missão nobre: realizar sonhos & $\begin{array}{l}\text { O trabalho possibilita a realização de sonhos por } \\
\text { meio de financiamentos. Mostra-se imerso na } \\
\text { cultura organizacional: "[...] a empresa Ihe propõe } \\
\text { uma forma de vida de sucesso e uma missão nobre } \\
\text { a realizar" (FREITAS, 2000, p. 55). Projeta uma boa } \\
\text { autovalorização, com uma dose de regressão e } \\
\text { nostalgia, autocontrole, submissão e capacidade } \\
\text { de ajustamento e adequação ao ambiente. }\end{array}$ \\
\hline
\end{tabular}


continuação

\begin{tabular}{|c|c|}
\hline Fonte: P5RF34, 16-12. & $\begin{array}{l}\text { Foi destituída da função de gerente geral como } \\
\text { punição por ter liderado um movimento grevista } \\
\text { de gerentes em } 2016 \text {. Mostra-se revoltada. No } \\
\text { desenho há muitas e carregadas nuvens: a situação } \\
\text { está muito difícil. Espera o momento em que o } \\
\text { sol voltará a brilhar no seu trabalho. A locomotiva } \\
\text { está em movimento, em alta velocidade, pois } \\
\text { tem que correr para encontrar a luz. Projeta um } \\
\text { pobre ajustamento, hostilidade e agressividade em } \\
\text { relação ao ambiente, onde encontra repressão e } \\
\text { conflitos não resolvidos. Evidencia tristeza, mas } \\
\text { também confiança em si. }\end{array}$ \\
\hline $\begin{array}{c}\text { Merps } \\
\text { Austoio } \\
\text { Kucol } \\
\text { Rinotric } \\
\text { onte: P6RM34, 9-7. }\end{array}$ & $\begin{array}{l}\text { Representa a ambiguidade da carreira dos jovens } \\
\text { gerentes. De um lado aparece a velocidade da } \\
\text { ascensão na carreira; do outro, o quanto o sucesso } \\
\text { compromete a saúde, o lazer e o tempo com a } \\
\text { família, revelando-se, então, ilusório. A estabilidade } \\
\text { oferecida pelo concurso público é ilusão, "um } \\
\text { fantasma" com pesados grilhões. Ao lado de muita } \\
\text { racionalidade aparece amplitude de sentimentos e } \\
\text { inteligência concreta, mentalidade objetiva, lógica, } \\
\text { desenvolvimento racional e também espiritual. } \\
\text { Evidencia também o temperamento espontâneo, } \\
\text { sendo perceptíveis a natureza temperamental, o } \\
\text { desejo de conseguir algo e de se valorizar. }\end{array}$ \\
\hline Fonte: P7RF32, 7-4. & $\begin{array}{l}\text { Retrata a rotina atribulada da P7: "rebola" para } \\
\text { que o bambolê e os pratos que equilibra não } \\
\text { caiam, apesar do sistema que não funciona e } \\
\text { da pressão exercida pela presença do cliente. } \\
\text { Revela comportamento adaptativo, equilíbrio, } \\
\text { senso de auto direção, força dos desejos, além } \\
\text { de altruísmo, socialização, otimismo, sentimento } \\
\text { de expansão e progresso. Mostra certo medo de } \\
\text { ameaças ambientais, mas também vitalidade e } \\
\text { uso construtivo das próprias potencialidades. }\end{array}$ \\
\hline 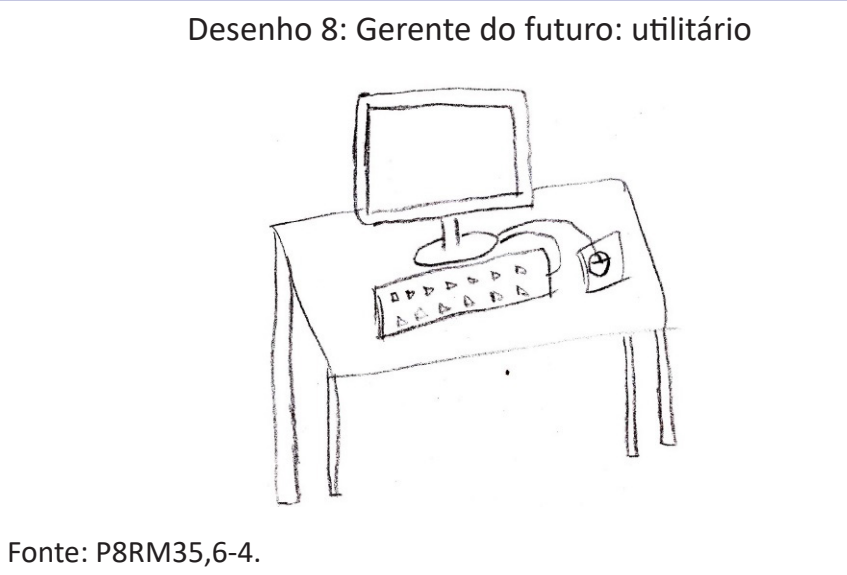 & $\begin{array}{l}\text { A função gerencial está em extinção, em pouco } \\
\text { tempo todos os negócios serão realizados por } \\
\text { computador. Mas esse processo não vai ser tão } \\
\text { rápido assim, ele ainda conseguirá aposentar-se. } \\
\text { Sonha com o retorno da incorporação da função ao } \\
\text { salário e com o horário de seis horas de trabalho } \\
\text { por dia. A figura fala de equilíbrio, ao lado de } \\
\text { introversão, inibição e repressão. Predominam } \\
\text { agudez, precisão e racionalidade, bem como o } \\
\text { esforço para o controle das emoções. O mundo } \\
\text { externo é percebido como incerto e imprevisível, há } \\
\text { necessidade de se defender de perigose, inclusive, } \\
\text { guardar dinheiro para o caso de perder a função. }\end{array}$ \\
\hline
\end{tabular}


continuação

\begin{tabular}{|c|c|}
\hline Fonte: P9RF33,8-2. & $\begin{array}{l}\text { Para explicar sua visão do mundo do trabalho } \\
\text { do jovem gerente de banco público, P9 trouxe } \\
\text { uma "representação simbólica" (AUGRAS, 1998). } \\
\text { Esse símbolo ressalta a função social do banco, a } \\
\text { satisfação por fazer diferença para as pessoas, a } \\
\text { missão organizacional, transmitida de geração a } \\
\text { geração, dando sentido ao trabalho diariamente } \\
\text { realizado, mostrando-se em conformidade com a } \\
\text { cultura organizacional. Projeta um perfil inseguro, } \\
\text { mas adaptativo, com predomínio de passividade, } \\
\text { expectativa diante da vida, inibição. Também mostra } \\
\text { sensibilidade, resistência psíquica e perseverança. }\end{array}$ \\
\hline Fonte: P10RM35,15-12. & $\begin{array}{l}\text { Expressa a importância da função social do banco, } \\
\text { levando recursos financeiros a todo o país, por } \\
\text { meio da atuação no comércio exterior e dos } \\
\text { financiamentos agrícolas. Trabalho significa renda. } \\
\text { Projeta passividade frente às decisões as quais } \\
\text { não pode influenciar do lugar que atualmente } \\
\text { ocupa, embora viva seus efeitos, a exemplo } \\
\text { da reestruturação do banco. Também mostra } \\
\text { objetivos elevados, porém sugere sentimentos } \\
\text { de inferioridade no ambiente. P10 tem noção de } \\
\text { passar uma imagem de poder que não corresponde } \\
\text { à realidade, afirma: "os outros pensam que eu } \\
\text { mando muito, quando eu não mando nada". }\end{array}$ \\
\hline Fonte: P11RM34, 11-8. & $\begin{array}{l}\text { O desenho representa uma folha em branco. P11 } \\
\text { negou-se a desenhar, argumentando que não se } \\
\text { considera gerente de banco público, por trabalhar } \\
\text { com clientes de alta renda e sua realidade ser } \\
\text { igual à dos bancos privados. Assim, P11 nega a } \\
\text { si mesmo, pouco preparado para lidar com as } \\
\text { contradições internas geradas pela organização } \\
\text { do trabalho. Mostra-se objetivo, descrevendo } \\
\text { com facilidade a parte operacional do trabalho, } \\
\text { por um lado. Por outro lado, apesar do discurso } \\
\text { racional, apresentava descamação de pele e } \\
\text { visível ansiedade. }\end{array}$ \\
\hline$\frac{1}{1}=$ & $\begin{array}{l}\text { Gerente do "carteirão", com mais de } 20 \text { mil clientes, } \\
\text { atende a demandas de diferentes assuntos, e } \\
\text { todos os prazos são "para ontem". De fato, “[...] } \\
\text { a temporalidade do trabalho leva à imposição de } \\
\text { ritmos, cadências, rupturas que se afastam do } \\
\text { tempo biológico, do tempo da vida humana [...], } \\
\text { o indivíduo submetido à gestão deve adaptar-se } \\
\text { ao tempo do trabalho" (GAULEJAC, 2014, p. 82). } \\
\text { Psicólogo e psicanalista, P12 projeta inadequação } \\
\text { e rejeição pelo ambiente, porém possui recursos } \\
\text { de autovalorização e equilíbrio, bem como senso } \\
\text { de auto direção. Evidencia hipersensibilidade, } \\
\text { delicadeza e submissão, emotividade, flexibilidade } \\
\text { e orientação instintiva, dissonando do ambiente } \\
\text { e das suas atividades no cotidiano. }\end{array}$ \\
\hline
\end{tabular}


continuação

\begin{tabular}{|c|c|}
\hline Fonte: P13R27, 4-2,5. & $\begin{array}{l}\text { Gerente do escritório virtual, segmento de alta } \\
\text { renda. Os post-its desenhados são lembretes } \\
\text { para não esquecer as demandas, múltiplas e } \\
\text { imediatas, as quais o "mantêm em alta adrenalina" } \\
\text { o tempo todo. Ser gerente de banco público é } \\
\text { uma "loucura". Projeta desinibição, sentimento } \\
\text { de expansão, atitude de expectativa diante da } \\
\text { vida. Mostra capacidade de manter o equilíbrio } \\
\text { da personalidade, perseverança emocional, } \\
\text { racionalidade. Sente-se bem em relação ao trabalho } \\
\text { e espera novas oportunidades de crescimento } \\
\text { na carreira. }\end{array}$ \\
\hline Fonte: P14RM29, 6-2. & $\begin{array}{l}\text { O banco é muito bom. P14 tem gratidão pela } \\
\text { organização, a quem deve muito. As pessoas } \\
\text { podem não ser tão boas, mas o banco é "uma } \\
\text { mãe". Estava "sem perspectivas profissionais" } \\
\text { após o serviço militar, e o banco surgiu como } \\
\text { tábua de salvação. Mesmo assim, procura "outra } \\
\text { coisa pública", mais tranquila, sem sobressaltos, } \\
\text { alinhado à figura, que projeta busca de adaptação } \\
\text { mediante conflitos. Entende que "bancário não é } \\
\text { profissão", por isso, estuda incansavelmente para } \\
\text { outros concursos. }\end{array}$ \\
\hline 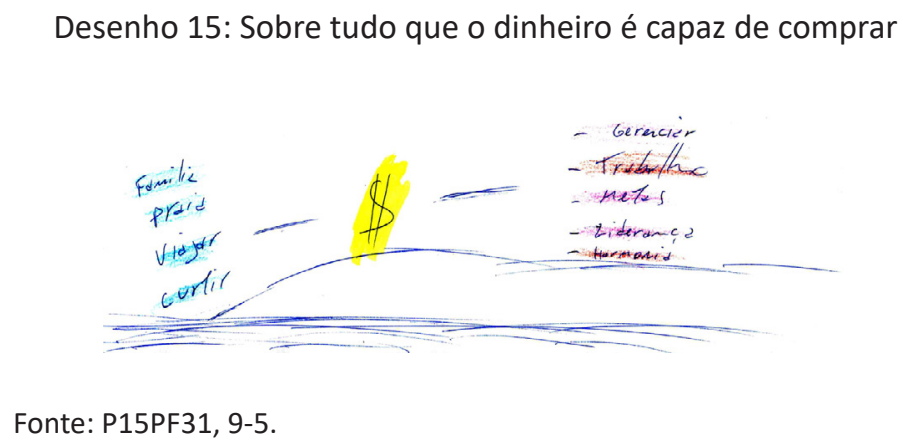 & $\begin{array}{l}\text { É hipocrisia dizer que se trabalha por satisfação } \\
\text { pessoal. P15 trabalha para gastar, viajar, curtir a } \\
\text { vida. É o dinheiro o parâmetro definidor de suas } \\
\text { escolhas. Os aspectos projetivos evidenciam } \\
\text { comportamento adaptativo, valorização de si } \\
\text { mesma, orientação para o concreto, contato com } \\
\text { a realidade, controle das emoções pela razão } \\
\text { e certa obstinação e teimosia. Depois de cinco } \\
\text { vestibulares, desistiu da medicina e encontrou no } \\
\text { banco satisfação. Hoje não se vê fazendo outra } \\
\text { coisa, preparou-se para isso e é boa no que faz. }\end{array}$ \\
\hline $\begin{array}{l}\text { Desenho 16: Este lado do paraíso: } \\
\text { futebol, churrasco, bom chimarrão } \\
\text { Realis odo An'jos }\end{array}$ & $\begin{array}{l}\text { O trabalho significa "quase tudo". Sente-se realizado, } \\
\text { pelos amigos e pelo sucesso financeiro e profissional } \\
\text { alcançados no trabalho. O que mais importa é } \\
\text { encontrar os amigos, jogar futebol e saborear um } \\
\text { churrasco depois do expediente. Irrita-se com os } \\
\text { colegas não tão comprometidos, os quais não } \\
\text { pode demitir e que deveriam envergonhar-se por } \\
\text { receberem salário desproporcional ao que produzem. } \\
\text { Aplica-se a ele a afirmação de que "os que resistem } \\
\text { ao objetivo de ser número um são pesos mortos" } \\
\text { (GAULEJAC, 2014, p. 173). Gosta mais das pessoas } \\
\text { que trabalham duro, focadas no alcance dos objetivos } \\
\text { organizacionais, ao modo do trabalhador golem } \\
\text { aristocrata, aquele que faz os outros produzirem, } \\
\text { exerce supervisão e controle, um "manipulado } \\
\text { que manipula os objetos, os processos e os outros } \\
\text { trabalhadores" (THIRY-CHERQUES, 2004, p. 37). Se } \\
\text { pudesse escolher outra carreira, seria político. A } \\
\text { afetividade é regulada pelo predomínio da razão. }\end{array}$ \\
\hline
\end{tabular}




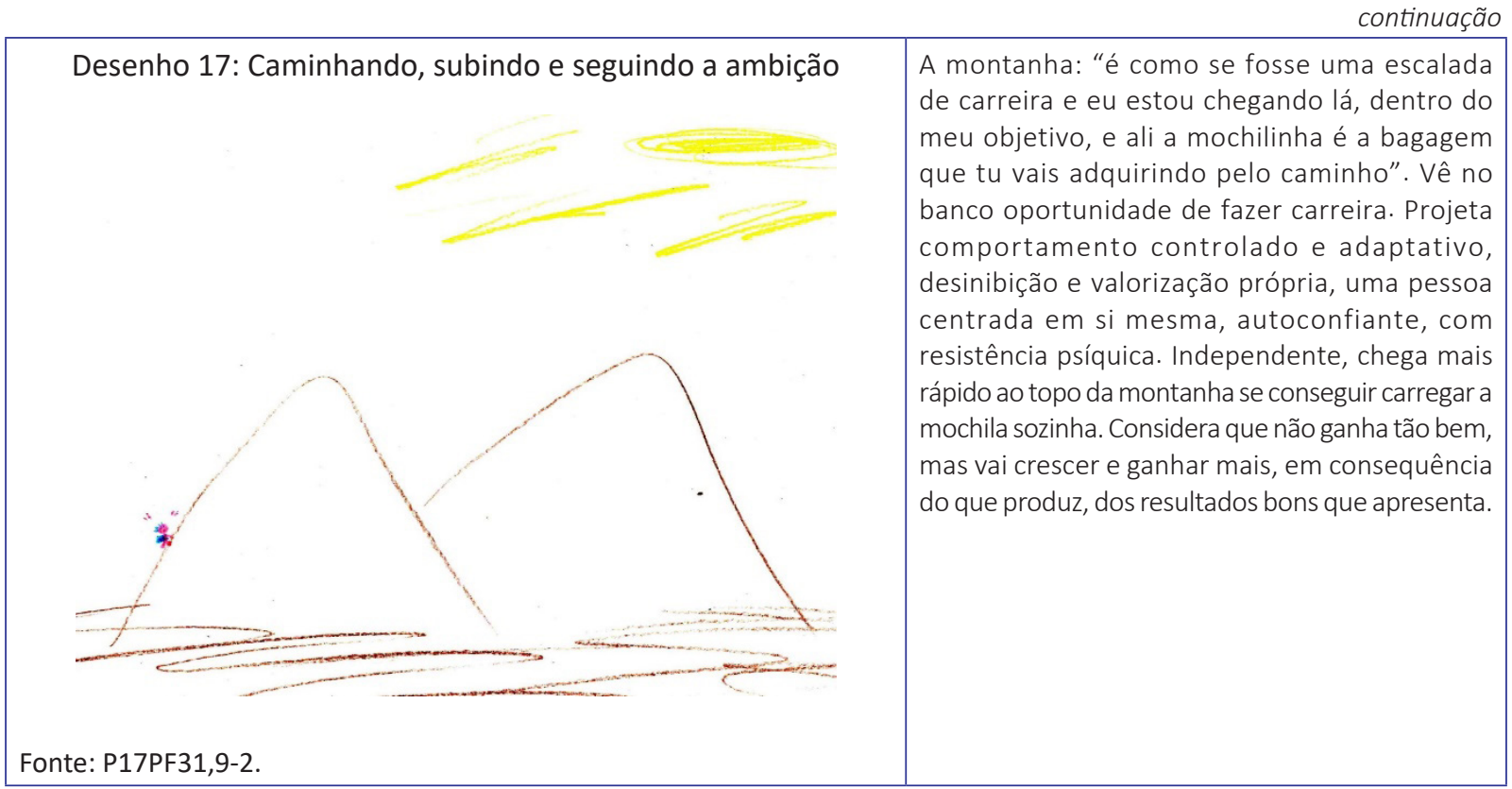

Fonte: Elaborado pelos autores.

Emerge dos discursos uma realidade marcada por ambiguidade, pois a organização, na busca incessante por resultados financeiros, provê e protege ao mesmo tempo que ameaça e pune. A balança inclina-se ora para a satisfação com o salário, com o poder de consumo e com o sucesso, ora para metas e cobranças, sem as condições necessárias à realização. A rápida progressão é contrabalançada pelo risco de perda da função de confiança, de modo semelhante à contradição entre prisão e liberdade que Salles e Costa (2013) identificaram nas representações de trabalhadores confinados. O jovem gerente conquista a autonomia financeira, mas aprisiona-se à própria ambição, pois precisa trabalhar cada vez mais para manter a função gerencial (MORGAN, 2011; ENRIQUEZ, 2014).

Os jovens gerentes buscam formas adaptativas de enfrentar a realidade, uma vez que a produção dos sentidos do trabalho é atravessada por contradições, superficialidade e alienação perante os fatos. Defendem o amor que sentem pela organização, projetando os problemas nos gestores ou no governo, como estratégia defensiva perante as representações de conotação negativa. A percepção do trabalho torna-se, para esses gerentes, objetivada e compreensível, emoldurada política e ideologicamente, conforme as características do meio e da formação sociocultural de cada participante e do grupo - criando-se um senso comum acerca da vivência de ser gerente de banco público.

Alguns defendem o modelo privado, que permite demissões dos colegas que não se sujeitam à busca desenfreada pelo resultado financeiro. Aproximam-se, assim, do perfil que Enriquez (2002, p. 17) identifica como tecnocrata, para quem "[...] os outros são vistos somente através de seu valor econômico atual, pois o tecnocrata não percebe no mundo outra coisa senão aquilo que the permita trocas econômicas cada vez mais vantajosas".

Os desejos de mudança, de modernização e agilização de processos, de redução da ingerência política e de estabelecimento da meritocracia coabitam com o medo da perda do próprio lugar nesse espaço.

Moscovici $(2015$, p. 61) sustenta que "[...] coisas que não são classificadas e que não possuem nome são estranhas, não existentes e ao mesmo tempo ameaçadoras". A ancoragem e a objetivação permitem classificar cada evento, dando-lhe um nome, tornando-o assim uma realidade concreta, integrada ao pensamento. As histórias pessoais contadas pelos participantes forneceram elementos que possibilitam compreender os esquemas de valores e crenças que lhes foram ensinados e são trazidos ao momento atual por processos mnemônicos e pela comunicação.

Observam-se padrões persistentes que revelam consensos e confluências de opiniões entre os participantes, ainda que circunstanciais, os quais permitem o arranjo de uma interpretação conjunta, como sugerido por Yin (2016). Assim, no Quadro 2 descrevem-se, em conjunto, os processos de elaboração e a identificação das representações sociais do trabalho dos jovens 
gerentes. Com base nos recortes das entrevistas e nas complementações de frases, foram reunidos elementos dos discursos que revelam o que ancora (A) cada uma das 37 representações, bem como as ideias e conceitos em que são objetivadas (O).

\section{Quadro 2}

Processo de ancoragem e objetivação das representações sociais

\begin{tabular}{|c|c|c|}
\hline \multicolumn{2}{|r|}{ Ancoragem (elementos dos discursos) } & $\begin{array}{c}\text { Objetivação } \\
\text { (ideias/conceitos) }\end{array}$ \\
\hline $\mathrm{AO} 1$ & $\begin{array}{l}\text { A remuneração é importante; o meu salário hoje, a minha estabilidade, é muito melhor } \\
\text { do que o dos colegas que se formaram comigo; aqui tem 13o e 14o salários, PLR, plano de } \\
\text { saúde, ticket alimentação bom; o salário dos amigos é menor; trabalho significa só o ganhar } \\
\text { dinheiro; os produtos remuneram bem; só estou aqui porque eu dependo para pagar minhas } \\
\text { contas; o salário de gerente é muito acima da média de mercado; eu vim de outros dois } \\
\text { serviços públicos de salário bem menor; o salário é o mais importante; trabalhar é uma forma } \\
\text { de manter um padrão de vida legal, desfrutar de lazer; eu trabalho por dinheiro, acho uma } \\
\text { hipocrisia a gente dizer que trabalha porque gosta, eu trabalho porque eu ganho para isso, } \\
\text { senão ficava em casa vendo televisão. }\end{array}$ & $\begin{array}{l}\text { Salário bom } \\
\text { e benefícios }\end{array}$ \\
\hline $\mathrm{AO} 2$ & $\begin{array}{l}\text { Eu fui promovido muito rápido; tem oportunidade de fazer carreira; assim que acabei a } \\
\text { faculdade, virei gerente, e dois anos depois, gerente geral; em seis meses eu virei assistente } \\
\text { e já ganhava mais do que como advogado; eu era psicóloga em uma empresa de vigilância } \\
\text { onde não tinha possibilidade de crescimento; em três anos virei gerente de atendimento, } \\
\text { depois de relacionamento, aí passei para a alta renda, gerente de administração e agora } \\
\text { gerente geral; minha ascensão foi muito rápida, meteórica, o pessoal das antigas demorava } \\
\text { bem mais tempo para ir galgando funções. }\end{array}$ & Rápida progressão \\
\hline $\mathrm{AO} 3$ & $\begin{array}{l}\text { A convivência com os colegas é importante; os clientes esperam duas, três horas para falar } \\
\text { comigo, eles confiam em mim; eu tenho amigos que eu fiz dentro do banco; algumas das } \\
\text { partes boas são os pares; o melhor do meu trabalho é o contato com as pessoas; eu tenho } \\
\text { amigo do banco que é meu padrinho de casamento; o melhor que eu fiz no banco são meus } \\
\text { amigos; eu me abasteço com pessoas. }\end{array}$ & Inter-relações pessoais \\
\hline $\mathrm{AO} 4$ & $\begin{array}{l}\text { Os concursos te dão mais segurança; estabilidade não, somos CLT; aqui o retorno é fixo, fora } \\
\text { não é fixo; tive uma empresa de jornalismo, é muito difícil lidar com funcionários; tenho medo } \\
\text { de perder o que conquistei e passar de novo o que já passei na minha infância e na minha } \\
\text { adolescência, ainda vejo o banco, por ser público, com mais estabilidade que no mercado } \\
\text { privado; trabalhar significa segurança; minha mãe tinha uma escola particular, e uma sócia, a } \\
\text { gente via a dificuldade de manter uma empresa neste país; te dá muita tranquilidade, saber } \\
\text { que todo dia } 25 \text { tu vais receber teu salário. }\end{array}$ & $\begin{array}{l}\text { Estabilidade } \\
\text { e segurança }\end{array}$ \\
\hline AO5 & $\begin{array}{l}\text { O que me motiva é a conquista, você estar cada dia se melhorando, se superando; o trabalho } \\
\text { representa orgulho e satisfação; eu sou considerada uma das melhores vendedoras do banco, } \\
\text { para mim as metas não são difíceis de cumprir; estou bem tranquilo na minha função, estou } \\
\text { bem posicionado. }\end{array}$ & Sucesso \\
\hline AO6 & $\begin{array}{l}\text { A organização e eu temos um caso de amor (com muitos desentendimentos), sou muito } \\
\text { grato por tudo que conquistei por trabalhar nessa empresa; a empresa e eu nos entendemos; } \\
\text { agradeço por ter um emprego bom, eu vejo meus colegas que são formados, têm experiência } \\
\text { e não estão muito bem; a empresa é excelente, uma mãe, as pessoas podem não ser, mas } \\
\text { o banco é muito bom, devo muito ao banco; amo o banco e amo ele até quando odeio ele. }\end{array}$ & Amor e gratidão \\
\hline $\mathrm{AO7}$ & $\begin{array}{l}\text { A rotina é bem dinâmica, todo dia tem uma coisa nova; gosto de aprender muito com as } \\
\text { pessoas... parece um jargão, mas eu consigo absorver aprendizado em qualquer situação; é } \\
\text { uma experiência nova todo dia, te dá uma maturidade. }\end{array}$ & Aprendizado \\
\hline $\mathrm{AO8}$ & $\begin{array}{l}\text { A gente paga os servidores do estado; fazemos arrecadação de impostos; sempre gostei de } \\
\text { habitação, é o cliente feliz, realizando os sonhos dele; meu trabalho significa dinheiro que o } \\
\text { banco mexe no país, para a agricultura, para o comércio exterior; trabalho com significado? } \\
\text { tem que ver se estou fazendo diferença na comunidade; trabalho é algo que se faz para } \\
\text { construir alguma coisa socialmente. }\end{array}$ & Função social \\
\hline AO9 & $\begin{array}{l}\text { O negócio é segurança, segurança financeira, ficar mais velho e não se preocupar com } \\
\text { dinheiro; eu me vejo aposentado no banco, não sou empreendedor; no momento eu tenho } \\
\text { medo de uma aposentadoria apertada, atendo muito beneficiário do INSS, sei que a renda } \\
\text { cai bastante lá na frente. }\end{array}$ & $\begin{array}{c}\text { Aposentadoria } \\
\text { tranquila }\end{array}$ \\
\hline
\end{tabular}


continuação

\begin{tabular}{|c|c|c|}
\hline \multicolumn{2}{|r|}{ Ancoragem (elementos dos discursos) } & \multirow{2}{*}{$\begin{array}{c}\begin{array}{c}\text { Objetivação } \\
\text { (ideias/conceitos) }\end{array} \\
\text { Independência } \\
\text { financeira, sustento }\end{array}$} \\
\hline A010 & $\begin{array}{l}\text { O trabalho é uma imposição, o sistema exige que eu trabalhe para me sustentar; ter um bom } \\
\text { emprego e não depender de terceiros financeiramente; trabalhar significa o meio de obter } \\
\text { o meu sustento e de minha família. }\end{array}$ & \\
\hline A011 & $\begin{array}{l}\text { Eu lido diretamente com os sócios da empresa; eu não tinha pretensão de me tornar gerente } \\
\text { geral, mas agora comecei a mudar. }\end{array}$ & Poder \\
\hline $\mathrm{AO} 12$ & $\begin{array}{l}\text { Pares: a gente tenta se unir e trabalhar em equipe; com todos juntos é mais fácil alcançar } \\
\text { os objetivos. }\end{array}$ & Trabalho em equipe \\
\hline $\mathrm{AO} 13$ & $\begin{array}{l}\text { Carteira tem meta, agência tem meta, matrícula tem meta; a empresa só pensa em lucro, } \\
\text { nos vê como números; temos vivido com campanha, desafio semanal, objetivos dinâmicos; } \\
\text { se eu tivesse que escolher outro trabalho seria uma coisa pública, mas sem metas, sem } \\
\text { tanta cobrança; todo dia é o "dia mais importante do mês", o resultado não é cumulativo, } \\
\text { você não respira; não me identifico muito com o serviço do gerente, com as metas, o tipo de } \\
\text { cobrança; a gente tem meta de produto, de volume de negócios, de despesa, de cobrança, } \\
\text { de inadimplência, a gestão da agência e da carteira. }\end{array}$ & Metas, cobranças \\
\hline $\mathrm{AO} 14$ & $\begin{array}{l}\text { Tem dia que a gente não dorme; há muitas pessoas afastadas por problemas psicológicos; a } \\
\text { gente não consegue desligar do trabalho quando chega em casa; meus exames e tratamentos... } \\
\text { estou deixando para lá... estou doente, somatizo muito, passo mal, dor de cabeça, irritado, } \\
\text { dor aqui, dor ali, eu entro em férias, tudo passa; depois que entrei no banco, minha agitação } \\
\text { aumentou muito, hoje sou hiperativo; eu tenho dor de cabeça, às vezes, se tem algum } \\
\text { estresse, né, que está somatizando; eu tinha pressão alta, tinha dificuldades no trabalho, } \\
\text { cheguei a ter } 141 \text { quilos, é uma fuga, tem que descarregar em alguma coisa, uns na bebida, } \\
\text { uns na comida, eu comia; não tinha rotina, ficava trabalhando direto sem fazer horário de } \\
\text { almoço; está faltando tempo para o exercício físico, não consigo perder os } 30 \text { quilos que } \\
\text { ganhei no banco, tenho falta de ar, o sedentarismo traz consequências...circulação...varizes, } \\
\text { inchaço, retenção de líquido, enxaqueca, dor de cabeça, dor nos ombros, dor nas mãos, } \\
\text { olhos cansados... está piorando... }\end{array}$ & Saúde fragilizada \\
\hline $\mathrm{AO} 15$ & $\begin{array}{l}\text { Hoje eu não sei o que faria se perdesse a função, o salário cairia de } 13 \text { para } 3 \text { mil; eu evito fazer } \\
\text { dívidas a longo prazo; perder a função reduz muito o salário, o gerente de relacionamento } \\
\text { ganha } 8 \text { mil, cai para uns } 4 \text {; eu vim para esta agência por medo de perder a comissão com } \\
\text { a reestruturação; é um instrumento de barganha, se você não bate a meta, amanhã você } \\
\text { pode não estar nesta comissão; três avaliações ruins, você pode perder esta comissão; a } \\
\text { maior parte do salário é a comissão, se eu perder, passo a ganhar menos da metade de hoje. }\end{array}$ & $\begin{array}{l}\text { Medo de perder } \\
\text { a função }\end{array}$ \\
\hline A016 & $\begin{array}{l}\text { Quanto mais você vende, mais trabalho retorna para você; minha rotina é estressante, é eu e } \\
\text { eu; agora ninguém mais tem apoio; tiraram as pessoas que ajudavam a gente; sobrecarrega } \\
\text { quem está trabalhando nas agências. }\end{array}$ & Falta de equipe \\
\hline $\mathrm{AO} 17$ & $\begin{array}{l}\text { Você fica muito com tudo... muito pressionado; outro dia não consegui atender por falta de } \\
\text { tempo, aí recebi ouvidoria; é tudo para ontem, tudo com ansiedade, com agonia, tudo é um } \\
\text { problema enorme; são muitas tarefas, tarefas que são "cumpríveis", só que não no prazo que } \\
\text { o banco quer; ser bancário é uma correria, não momentânea, o tempo todo. }\end{array}$ & Prazos curtos \\
\hline A018 & $\begin{array}{l}\text { Tenho } 900 \text { clientes que me demandam; e ainda tem e-mail e WhatsApp de clientes; excesso } \\
\text { de trabalho, é muita coisa ao mesmo tempo, todo mundo interrompendo, não consigo } \\
\text { terminar um processo e parece que estou em uma maratona desde a hora que eu chego } \\
\text { até a hora que eu saio. }\end{array}$ & Demandas múltiplas \\
\hline A019 & $\begin{array}{l}\text { A empresa está passando por uma reestruturação muito grande, está fechando algumas } \\
\text { agências, perdendo funções gerenciais, a gente não sabe o que vai acontecer; o número de } \\
\text { gerentes tem encolhido com as reestruturações. }\end{array}$ & Reestruturação \\
\hline $\mathrm{AO} 20$ & $\begin{array}{l}\text { Tenho medo de ficar desempregado; tenho medo de perder o emprego, gerente, a gente se } \\
\text { adapta, mas o emprego... tem muito ex-bancário taxista aqui no Rio. }\end{array}$ & $\begin{array}{l}\text { Medo de perder } \\
\text { o emprego }\end{array}$ \\
\hline $\mathrm{AO} 21$ & $\begin{array}{l}\text { Eu não dou conta de fazer mais nada, eu entro às } 9 \text { h e saio às } 18 \mathrm{~h} \text {; vim para o banco porque } \\
\text { aqui eram } 6 \text { horas; vim na ilusão de que eu poderia trabalhar } 6 \text { horas. }\end{array}$ & $\begin{array}{l}\text { Carga horária } \\
\text { de oito horas }\end{array}$ \\
\hline $\mathrm{AO} 22$ & $\begin{array}{l}\text { A incorporação está praticamente proibida; a gente não tem mais incorporação de função, } \\
\text { me preocupo porque uma pessoa que está gerente há } 20 \text { anos, ou ela para ou ela morre. }\end{array}$ & $\begin{array}{l}\text { Medo de perder a } \\
\text { incorporação de função }\end{array}$ \\
\hline $\mathrm{AO} 23$ & Fui destituída porque liderei um movimento grevista de gerentes. & Destituição \\
\hline
\end{tabular}




\section{Ancoragem (elementos dos discursos)}

continuação

\begin{tabular}{|c|c|c|}
\hline \multicolumn{2}{|r|}{ Ancoragem (elementos dos discursos) } & \multirow{2}{*}{$\begin{array}{c}\text { Objetivação } \\
\text { (ideias/conceitos) } \\
\text { Rebaixamento }\end{array}$} \\
\hline $\mathrm{AO} 24$ & $\begin{array}{l}\text { Se você for rebaixado para agência de menor porte, o salário de gerente geral cai, conforme } \\
\text { a classificação da agência; os gerentes PJ que não tiverem } 300 \text { clientes na carteira serão } \\
\text { rebaixados. }\end{array}$ & \\
\hline $\mathrm{AO} 25$ & $\begin{array}{l}\text { Tem que produzir e tem outro que quer o seu lugar; tem que vender toda a linha de seguro } \\
\text { de vida, de carro, residência, consórcio... não sei como eles fazem, realmente eu não sei, } \\
\text { senão eu fazia também. }\end{array}$ & Competição interna \\
\hline AO26 & $\begin{array}{l}\text { Talvez haja contratação de bancários temporários, até para gestores de agência, gerentes } \\
\text { de carteira podem ser terceirizados. }\end{array}$ & Terceirização \\
\hline $\mathrm{AO} 27$ & $\begin{array}{l}\text { Já fui assaltada, arma na cabeça, aquela coisa; tenho medo da violência, em relação a } \\
\text { segurança, assaltos. }\end{array}$ & Assaltos \\
\hline $\mathrm{AO} 28$ & $\begin{array}{l}\text { Sabia que para ter um bom emprego, teria que estudar muito, não queria ter empregos } \\
\text { ruins como meus irmãos e meu pai; meu pai queria que eu fosse advogado, para passar no } \\
\text { tribunal do trabalho; muitas vezes a gente pensa que está numa prisão porque... o fantasma } \\
\text { do concurso público, a gente tem medo de sair dele; fiz } 14 \text { concursos públicos, passei para } \\
\text { este; minha mãe me inscreveu no concurso, meus pais são funcionários aposentados; queria } \\
\text { estar em outro lugar, mas em alguma coisa na área pública; meu pai era bancário do Banco } \\
\text { do Brasil; meu pai era servidor público, então, desde pequeno eu sempre escutei que a } \\
\text { estabilidade de vida estaria ligada a um concurso; minha mãe é funcionária pública e ela } \\
\text { sempre me incentivou a fazer concurso. }\end{array}$ & Concurso \\
\hline AO29 & $\begin{array}{l}\text { "Lança aquela operação lá porque o diretor mandou!"; o cenário político a longo prazo... eu } \\
\text { não vejo futuro para a empresa; o governo, ele está intencionalmente sucateando a empresa; } \\
\text { o pior do meu trabalho é a volatilidade trazida por políticos do governo. }\end{array}$ & Ingerência política \\
\hline $\mathrm{AO} 30$ & $\begin{array}{l}\text { Falta um pouco de motivação a alguns colegas, falta as pessoas focarem em resultado; há } \\
\text { pessoas encostadas, que têm costas largas; a gente tem um quadro de funcionários que } \\
\text { deixa a desejar, pouco comprometido, que está só esperando a aposentadoria; não gosto } \\
\text { da postura de só ter direitos e não ter nenhum dever. }\end{array}$ & $\begin{array}{l}\text { Algumas pessoas pouco } \\
\text { comprometidas }\end{array}$ \\
\hline A031 & $\begin{array}{l}\text { Não tem processo seletivo para gerente geral, é indicação mesmo; você vê pessoas menos } \\
\text { capazes do que você entrando na sua frente; o governador escolhe administradores técnicos } \\
\text { para gerir o banco; tem gestores muito ruins, que não sabem nem do que é feito o nosso } \\
\text { índice de desempenho. }\end{array}$ & Nomeações políticas \\
\hline $\mathrm{AO} 32$ & $\begin{array}{l}\text { Eu materializo o banco público nas amarras, na licitação, da burocracia; aqui se eu quiser pintar } \\
\text { a parede tenho que passar por uma licitação, demora mais de ano; esbarra em burocracia, } \\
\text { acordos, questões legais. }\end{array}$ & Burocracia \\
\hline $\mathrm{AO} 33$ & $\begin{array}{l}\text { Não tem punição; o banco não é rigoroso, pelo contrário, o banco é muito benevolente; o } \\
\text { grande problema do nosso banco, o fato de ser concurso, fato de a gente às vezes não poder } \\
\text { cobrar e o banco não pode fazer uma demissão. }\end{array}$ & Impunidade \\
\hline $\mathrm{AO} 34$ & $\begin{array}{l}\text { Privatização é algo que me gera medo hoje; em caso de privatização, é claro que vai demitir, } \\
\text { mas não todos, o banco tem } 12 \text { mil funcionários e eu me garanto entre três mil, meu } \\
\text { currículo e meu desempenho me garantem, a privatização não me preocupa; privatização } \\
\text { é o caminho natural. }\end{array}$ & Privatização \\
\hline $\mathrm{AO} 35$ & $\begin{array}{l}\text { Para mim, tudo bem, os profissionais que trabalham direitinho, que dão resultado, vão ter } \\
\text { espaço. }\end{array}$ & Meritocracia \\
\hline $\mathrm{AO} 36$ & $\begin{array}{l}\text { A falta de governança corporativa, a falta de transparência e critérios para promoções/ } \\
\text { destituições e a hipocrisia dos superiores; é um lugar maravilhoso para se trabalhar, o } \\
\text { problema é quem está no controle hoje; sinto falta de ter tido um tutor, um mentor; manda } \\
\text { quem pode, obedece quem tem juízo. }\end{array}$ & $\begin{array}{l}\text { Falta de lideranças } \\
\text { inspiradoras e confiáveis }\end{array}$ \\
\hline $\mathrm{AO} 37$ & $\begin{array}{l}\text { Meu principal problema aqui é a falta de estrutura tecnológica; os sistemas funcionam? não, } \\
\text { isso não muda; a gente não tem estrutura para ser gerente, não temos tecnologia nem mão } \\
\text { de obra qualificada; o sistema nem sempre funciona como desejamos. }\end{array}$ & Tecnologia insuficiente \\
\hline
\end{tabular}

Fonte: Elaborado pelos autores. 
Assim, na estrutura das representações sociais dos jovens gerentes, emergiram três núcleos centrais de distintas conotações: conotação positiva, "organização provedora e protetora" (AO1 a AO12); conotação negativa, "organização cobradora e punidora, com foco no lucro" (AO13 a AO27), e conotação variável (ora conotação positiva, ora negativa, dependendo da circunstância), "organização pública" (AO28-AO37). São dimensões rígidas das representações (núcleos centrais), em torno das quais foram organizados e agrupados, por afinidade simbólica, os elementos constitutivos periféricos.

A Figura 2 apresenta as representações do grupo pesquisado. O número dentro das engrenagens informa quantos participantes referenciaram aquela representação. Mostra como as percepções da vida e do trabalho engendram-se ao modo de um sistema, uma engrenagem em movimento, na qual são (re)elaboradas continuamente as representações sociais do grupo, resultando de contínuos processos de ancoragem e objetivação, sob influência de experiências individuais, da cultura organizacional e da social.

Figura 2

Representações sociais do trabalho dos jovens gerentes de bancos públicos

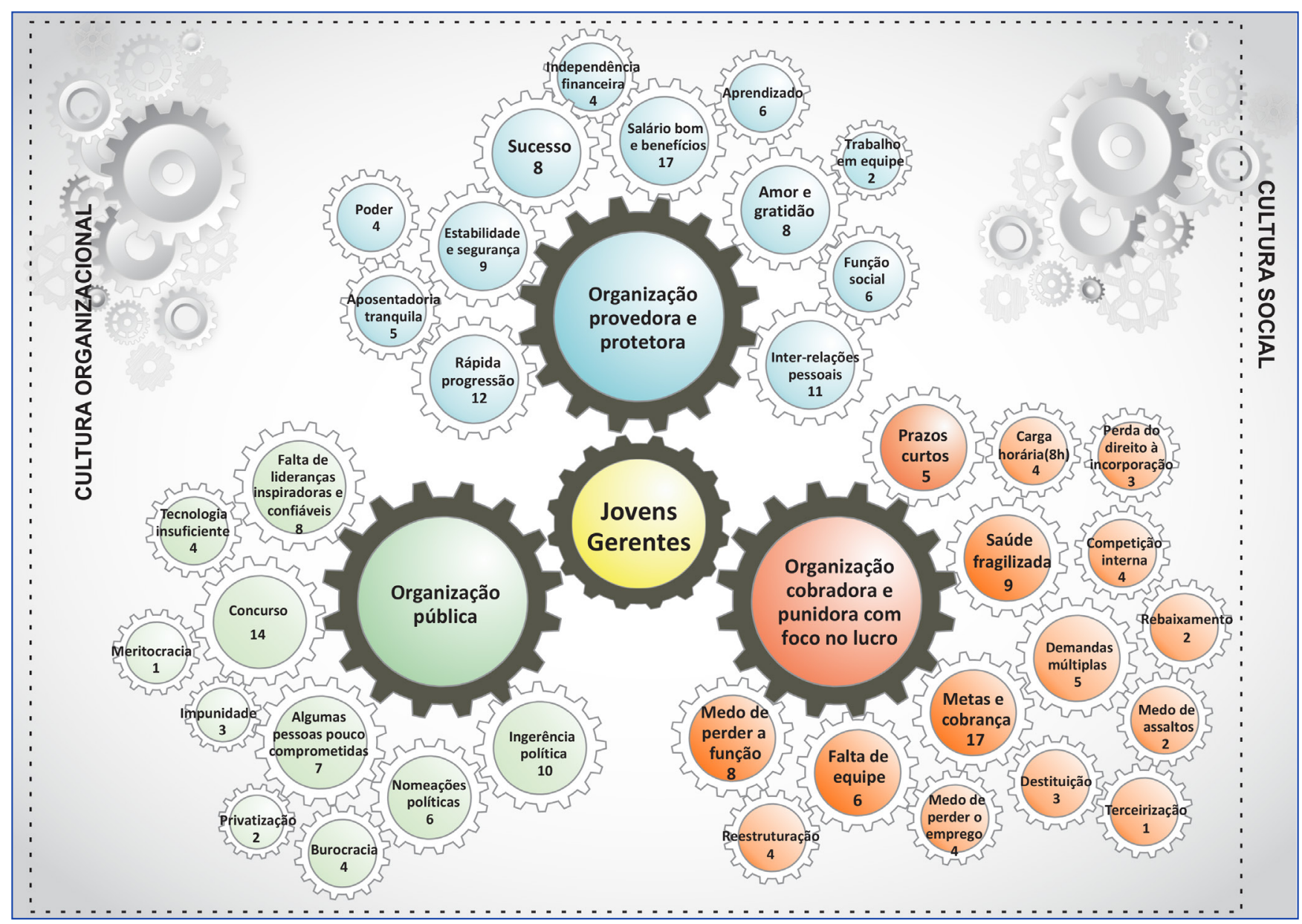

Fonte: Elaborada pelos autores.

Observa-se que o trabalho assume preponderantemente um sentido funcional e instrumental para esses jovens, tendo conotação positiva na medida em que proporciona os meios necessários à sobrevivência, bem como conforto e lazer, representada por "salário bom e benefícios". Essa representação guarda a característica da unanimidade, evidenciando que é a remuneração que move, precipuamente, os jovens gerentes.

Ao mesmo tempo, o trabalho é fatigante, assumindo conotação negativa em relação às condições de realização das tarefas. A cobrança por metas e resultados é outra representação que aparece com unanimidade entre os jovens gerentes, surgindo como fonte de males que os afligem, com impacto, inclusive, na saúde. No entanto, os sentimentos de amor, gratidão e 
admiração pela organização são fortes a ponto de neutralizar eventuais pensamentos e sentimentos negativos frente a eventos desagradáveis.

No dia a dia, realizam atividades operacionais e não participam de decisões estratégicas, que ocorrem no modelo top down. Portanto, resta-Ihes adequar-se às normas, construindo uma imagem em conformidade com as exigências, a fim de se manterem aptos ao cargo, em ambiente de muita competição, medo de perda da função e insegurança quanto ao futuro. Destituição significa risco de sentir-se incompetente, fracassado, e perder a condição de pertença, além do prejuízo à imagem frente a colegas, parentes, conhecidos e a si mesmo.

Em geral, os participantes são oriundos das classes populares, filhos de trabalhadores, agricultores, alguns funcionários públicos e até empregados de bancos públicos. Em detrimento da autorrealização e da saúde - cujos prejuízos aparecem em relatos sobre obesidade, manchas e descamação na pele, problemas de coluna, dores nas mãos, nos ombros e emoções negativas - mantêm-se na zona de conforto oferecida na gaiola de ouro, representada pelo bom salário, benefícios, segurança e estabilidade. Tudo isso revela o uso cada vez mais intenso das suas forças mentais, emocionais e físicas em benefício da ambição e do sucesso na carreira - como descrito na prisão psíquica de Morgan (2011).

Apesar de manifestarem que o melhor do trabalho é o contato com pessoas, o individualismo é uma constante. Os objetivos são individualizados, favorecendo a fragmentação dos laços afetivos. Evidenciou-se que esses jovens aderem ao discurso gerencial e estão de acordo com o modelo de gestão por resultados nas empresas públicas, em detrimento da função social. É consenso a necessidade de gerar lucros, pois acreditam ser essa a razão de as organizações existirem e ser esse o propósito de sua posição nelas.

O banco não surge como local para manifestação de emoções. Insatisfação, tristeza e tédio geram desconfiança sobre a capacidade produtiva dos indivíduos. Por isso, em geral, os jovens gerentes se mostram contidos e tentam transmitir tranquilidade. Resistir à pressão com equilíbrio e serenidade é condição para manter a credibilidade diante dos clientes e das chefias: esse comportamento é indicador dos mais aptos às promoções. Nesse sentido, aqui também se verificou que os jovens gerentes devem parecer bem, alegres e dispostos, dissimulando o sofrimento psíquico.

O que emana das evidências é um sentimento "opaco", desprovido de alegria genuína e entusiasmo em relação ao trabalho. Os sentimentos e percepções dos jovens gerentes são falseados e o artificialismo tecnocrata do meio financeiro de certo modo os faz alienados e pouco íntimos de si, seguindo o fluxo da rotina de trabalho. Reprimindo as emoções e naturalizando a busca de prazeres consumistas, vivem angustiados pelo medo da perda da estabilidade que talvez já nem tenham.

Não se trata de adotar uma abordagem uniformizadora em relação aos jovens gerentes, pois há pessoas que não se conformam ao esquema dado. Porém, têm poucas oportunidades de deixar que os conflitos reprimidos se libertem: a sobrevivência é impositiva e os ganhos secundários são atraentes. Também há um limite a partir do qual a pessoa reage: quando o núcleo central da empresa provedora e protetora é abalado, aí reside o estímulo para questionamentos. Seria necessário olhar de fora a situação, dissecar, analisar e reinterpretar a realidade sem ilusões nem utopias, compreender a dimensão simbólica que permeia as inter-relações e, com isso, correr o risco de desestabilizar o esquema.

A expectativa é priorizada em detrimento da evidência, visto que há forças incontroláveis agindo sobre os entes sociais, perante as quais nem sempre são os mais aptos que sobrevivem (Thiry-Cherques, 2004). Esses jovens gerentes acreditam que, por merecimento, serão poupados nos momentos difíceis da organização. Embora mudanças como o banco virtual, por exemplo, já estejam em operação, no seu imaginário sempre haverá necessidade de pessoas e os bons empregados têm seus lugares garantidos. Apesar do falseamento do julgamento apontado por Thiry-Cherques (2004), em momentos de crise e condições adversas, a reflexividade desperta e obriga a um olhar crítico para a realidade, provocando angústia e sofrimento, mas, também, superação. $O$ indivíduo fica cada vez mais vulnerável frente à organização, porém, tem capacidade reflexiva e deliberativa de "[...] se pensar no mundo, [...] pôr em questão a si mesmo e seu meio, [...] e pode pensar em alguma coisa diferente do que existe [...]" (GAULEJAC, 2014, p. 293). 


\section{CONCLUSÃO}

Muitos jovens estão em busca de um trabalho que tenha sentido e de locais seguros para o início da jornada profissional. Todavia, mudanças tecnológicas, legais e econômicas sinalizam que a tradicional estabilidade passa a ser um sonho. Na conjuntura atual, o prognóstico é de redução do número de postos de trabalho disponíveis nos bancos públicos. Estar em uma função de confiança que pode ser perdida mostra que o sucesso é ilusório, seja pelo preço, seja porque pode ser efêmero aspectos presentes nos discursos e nos desenhos dos participantes da pesquisa -, representado e verbalizado por um deles como o "meteoro da ilusão".

Os resultados desta pesquisa sobre o sentido do trabalho com jovens gerentes confirmam, por unanimidade, a associação entre trabalho e dinheiro. Além disso, as inter-relações pessoais emergem como importante representação social do trabalho dos jovens gerentes, e podem ser mais robustas estimulando-se a cooperação.

Não há finitude para a busca dos sentidos do trabalho e para a elaboração de novas representações. O processo é dinâmico, e as representações ora apresentadas estão vinculadas a um grupo particular, com características socioculturais específicas e em cenário restrito, de modo que os resultados não devem ser generalizados. Ao contrário, pelas limitações e restrições deste estudo, a quantidade de indagações sobre o tema aumentou e importa a realização de novas e complementares investigações. Recomenda-se, sobretudo, a ampliação para outras unidades/locais e para um número maior de jovens gerentes, bem como estender a outras profissões, além de um estudo longitudinal com os mesmos participantes.

Para uma possível apropriação dos resultados desta pesquisa pela prática organizacional, destacamos aspectos das representações vinculadas ao núcleo central "organização cobradora, punidora e com foco no lucro", cujo esquema periférico permite ações relativamente simples e imediatas. Nesse sentido, a redução de fatores estressores, sejam eles internos do sujeito ou externos, contextuais, pode ser, até certo ponto, alcançada pela gestão, por meio de ações preventivas ou interventivas no que respeita aos limites físicos, mentais e psicoafetivos dos indivíduos. Compete aos gestores considerar o nexo entre saúde e trabalho, mediando essa relação, envolvendo a todos na compreensão da situação e nos desdobramentos da função gerencial. A partir disso, é possível conduzir os processos de trabalho à consecução bem-sucedida de resultados sustentáveis, oferecendo serviços de qualidade, capazes de conquistar o envolvimento dos funcionários e a lealdade dos clientes.

Outras mudanças, não menos importantes, envolvem atuação política e podem ser mais demoradas, mas qualquer melhoria no processo estudado é importante para a solução de problemas humanos concretos, pois compreender melhor o trabalho é imprescindível para transformá-lo. 


\section{REFERÊNCIAS}

ABRIC, J. C. O estudo experimental das representações sociais. In: JODELET, D. (Org.). As representações sociais. Rio de Janeiro: UERJ, 2001. p. 154-172.

ALMEIDA, A.M.O; SANTOS, M.F.S; TRINDADE, Z.A. Teoria das Representações Sociais: 50 anos. Brasília: Technopolitik, 2014.

ANZIEU, D. Os métodos projetivos. Rio de Janeiro: Campus, 1978.

ARRUDA, A. Representações sociais: dinâmicas e redes. In: ALMEIDA, A. M. O.; SANTOS, M. F. S; TRINDADE, Z. A. Teoria das Representações Sociais: 50 anos. Brasília: Technopolitik, 2014, p. 442-491.

AUGRAS, M. A dimensão simbólica: o simbolismo nos testes psicológicos. 3. ed. Petrópolis: Vozes, 1998.

BRESSER-PEREIRA, L. C. Gestão do setor público: estratégia e estrutura para um novo Estado. In: BRESSER-PEREIRA, L. C.; SPINK, P. (Orgs.). Reforma do Estado e administração pública gerencial. Rio de Janeiro: FGV, 1998.

BRUNO, W. P. Bancários não são máquinas. In: SZNELWAR, L. (Org.). Saúde dos bancários. São Paulo: Publisher, 2011. p. 21-32.

CRESWELL, J. W. Projeto de pesquisa: métodos qualitativo, quantitativo e misto. 3. ed. Porto Alegre: Bookman Artmed, 2010.

DEJOURS, C. A banalização da injustiça social. Rio de Janeiro: Fundação Getulio Vargas, 1999.

DEJOURS, C.; ABDOUCHELI, E.; JAYET, C. Psicodinâmica do trabalho: contribuições da escola dejouriana à análise da relação prazer, sofrimento e trabalho. 2. ed. São Paulo: Atlas, 2009.

ENRIQUEZ, E. A organização em análise. Petrópolis: Vozes, 1997.

ENRIQUEZ, E. Vida psíquica e organização. In: MOTTA, F. C. P.; FREITAS, M. E. (Orgs.). Vida psíquica e organização. 2. ed. Rio de Janeiro: FGV, 2002. p. 11-22.

ENRIQUEZ, E. Jogos de poder na empresa: sobre os processos de poder e estrutura organizacional. São Paulo: Zagodoni, 2014.

FEDERAÇÃO BRASILEIRA DE BANCOS - FEBRABAN. Relatório Anual 2016. 2017. Disponível em: $<$ https://relatorioanual2016.febraban.org. $\mathrm{br} / \mathrm{pt} / \mathrm{download} /$ FEBRABAN_RA_16.pdf>. Acesso em: $06 \mathrm{fev} .2018$.

FLAMENT, C. Estrutura e dinâmica das representações sociais. In: JODELET, D. (Org.). As representações sociais. Rio de Janeiro: UERJ, 2001. p. 174-186.

FREITAS, J. A. S. B. Controladoras estrangeiras e conhecimento organizacional nas controladas brasileiras: estudo de caso nas áreas de varejo de duas organizações bancárias. 2005. Tese (Doutorado em Administração de Empresas) - Pontifícia Universidade Católica do Rio de Janeiro, Rio de Janeiro, 2005.

FREITAS, M. E. Cultura organizacional: identidade, sedução e carisma? 2. ed. Rio de Janeiro: FGV, 2000.

FREITAS, M. E. A questão do imaginário e a fronteira entre a cultura organizacional e a psicanálise. In: MOTTA, F. C. P; FREITAS, M. E. (Orgs.). Vida psíquica e organização. 2. ed. Rio de Janeiro: FGV, 2002.
GAULEJAC, V. A gestão como doença social: ideologia, poder gerencialista e fragmentação social. São Paulo: Ideias e Letras, 2014.

JINKINGS, N. Trabalho e resistência na fonte misteriosa. Campinas: Unicamp, 2002.

JODELET, D. Representações Sociais: um domínio em expansão. In: JODELET, D. (Org.). As representações sociais. Rio de Janeiro: UERJ, 2001. p. 17-44.

JODELET, D. O movimento de retorno do sujeito e a abordagem das representações sociais. Sociedade e Estado, v. 24, n. 3, p. 679712, 2009.

MARKOVÁ, I. The making of the theory of social representations. Cadernos de Pesquisa, v. 47, n. 163, p. 338-374, p. 2017.

MARTINS-SILVA P. O. et al. Teoria das representações sociais nos estudos organizacionais no Brasil: análise bibliométrica de 2001 a 2014. Cadernos EBAPE.BR, Rio de Janeiro, v. 14, n. 4, p. 891-919, 2016.

MÁXIMO, T. A. et al. Exigências nos percursos profissionais dos gerentes de banco. Psicologia e Sociedade, v. 23, n. 1, p. 66-74, 2011.

MORGAN, G. Imagens da organização. 15. reimp. São Paulo: Atlas, 2011.

MOSCOVICl, S. La psychanalyse, son image et son public. Paris: Presses Universitaires de France, 2004. Disponível em: <http://doi. org/10.3917/puf.mosco.2004.01>. Acesso em: 06 fev. 2018.

MOSCOVICl, S. Representações sociais: investigações em psicologia social. 11. ed. Petrópolis: Vozes, 2015.

MOTA, K. S. Trabalhar pra quê? Percepções sobre trabalho entre jovens de diferentes estratos sociais. 2012. Dissertação (Mestrado em Administração de Empresas) - Fundação Getulio Vargas, São Paulo, 2012.

PAGÈS, M. et al. O poder das organizações. São Paulo: Atlas, 2006.

RESENDE, S.; MENDES, A.M. A sobrevivência como estratégia para suportar o sofrimento no trabalho bancário. Revista Psicologia: Organização e Trabalho, v. 4, n. 1, p. 151-175, 2004.

SALLES, D. M. R.; COSTA, I. S. A. Representações do trabalho: estudo sobre confinamento na indústria petrolífera. RAE, v. 53, n. 3, p. 230242, 2013.

SELIGMANN-SILVA, E. Os riscos da insensibilidade. In: ARAÚJO, A. J. S. et al. (Orgs.). Cenários do trabalho: subjetividade, movimento e enigma. Rio de Janeiro: DP\&A, 2004. p. 51-72.

SILVA, M.C.; COSTA, I.S.A. Sobreviver ao trabalho: narrativas míticas na realidade organizacional. Revista de Administração Unimep, v.13, n. 1, p.141-164, 2015.

SILVA, M. L. E. Interpretação de testes projetivos: projeção e representação. Rio de Janeiro: Campus, 1981.

THIRY-CHERQUES, H. Sobreviver ao trabalho. Rio de Janeiro: FGV, 2004.

VAN KOLCK, O. L. Interpretação psicológica de desenhos. 2. ed. São Paulo: Pioneira, 1981.

YIN, R. K. Pesquisa qualitativa do início ao fim. Porto Alegre: Penso, 2016. 


\section{Elena Bandeira da Silva}

ORCID: https://orcid.org/0000-0002-9159-1250

Psicóloga e Mestre em Administração pela Universidade Estácio de Sá (UNESA), Rio de Janeiro - RJ, Brasil. E-mail: elenabandeira@hotmail.com

Isabel de Sá Affonso da Costa

ORCID: https://orcid.org/0000-0002-4386-9385

Doutora em Administração pela Fundação Getulio Vargas (FGV); Professora adjunta no Mestrado em Administração e Desenvolvimento Empresarial da Universidade Estácio de Sá (MADE/UNESA), Rio de Janeiro - RJ, Brasil. E-mail: isabel.costa@estacio.br

Jorge Augusto de Sá Brito e Freitas

ORCID: https://orcid.org/0000-0002-0371-0409

Doutor em Administração de Empresas pela Pontifícia Universidade Católica do Rio de Janeiro (PUC-Rio); Professor Adjunto no Mestrado em Administração e Desenvolvimento Empresarial da Universidade Estácio de Sá (MADE/UNESA), Rio de Janeiro - RJ, Brasil. E-mail: jasbfreitas@globo.com

Denise Medeiros Ribeiro Salles

ORCID: https://orcid.org/0000-0001-8378-7117

Doutora em Administração pela Fundação Getulio Vargas (FGV); Professora Adjunta na Universidade Federal Fluminense (UFF), Niterói - RJ, Brasil.

E-mail: denisesalles@id.uff.br 